\title{
Nitrite and Nitrate Levels of Gingival Crevicular Fluid and Saliva in Subjects with Gingivitis and Chronic Periodontitis
}

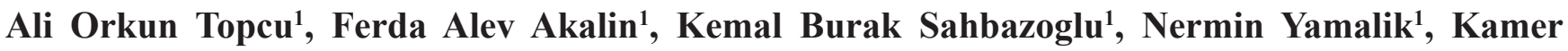 \\ Kilinc $^{2}$, Erdem Karabulut ${ }^{3}$, Tolga Fikret Tözüm ${ }^{1}$
}

${ }^{1}$ Department of Periodontology, Faculty of Dentistry, Hacettepe University, Ankara, Turkey.

${ }^{2}$ Department of Biochemistry, Faculty of Medicine, Hacettepe University, Ankara, Turkey.

${ }^{3}$ Department of Biostatistics, Faculty of Medicine, Hacettepe University, Ankara, Turkey.

\author{
Corresponding Author: \\ Tolga Fikret Tözüm \\ Department of Periodontology, Faculty of Dentistry \\ Hacettepe University \\ Sihhiye, 06100 Ankara \\ Turkey \\ Phone: +90 3123052237 \\ Fax: +903123104440 \\ E-mail: ttozum@hacettepe.edu.tr
}

\begin{abstract}
Objectives: Nitrosative stress plays an essential role in the pathogenesis of periodontal disease. The aim of this study is to analyze the gingival crevicular fluid and saliva nitrite and nitrate levels in periodontally healthy and diseased sites.

Material and Methods: A total of 60 individuals including, 20 chronic periodontitis and 20 gingivitis patients and 20 periodontally healthy controls participated in the present study. Probing depth, clinical attachment level, bleeding on probing, gingival index and plaque index were assessed, gingival crevicular fluid (GCF) and saliva samples were obtained from the subjects, including 480 GCF samples and 60 unstimulated whole saliva samples. Nitrite and nitrate were analyzed by Griess reagent.

Results: Total GCF nitrite levels were higher in gingivitis and periodontitis groups (1.07 [SD 0.62] nmol and 1.08 [SD 0.59] $\mathrm{nmol})$ than the control group $(0.83$ [SD 0.31$] \mathrm{nmol})(\mathrm{P}<0.05)$ but did not differ significantly between gingivitis and periodontitis groups $(\mathrm{P}>0.05)$. The difference in GCF nitrate level was not significant among the control, gingivitis and periodontitis groups (7.7 [SD 2.71] nmol, 7.51 [SD 4.16] nmol and 7.38 [SD 1.91] nmol). Saliva nitrite and nitrate levels did not differ significantly among three study groups. Saliva nitrate/nitrite ratios were higher in periodontitis and gingivitis groups than the control group. A gradual decrease in nitrate/nitrite ratio in GCF was detected with the presence of inflammation.

Conclusions: It may be suggested that nitrite in gingival crevicular fluid is a better periodontal disease marker than nitrate and may be used as an early detection marker of periodontal inflammation, and that local nitrosative stress markers don't show significant difference between the initial and advanced stages of periodontal disease.
\end{abstract}

Keywords: gingival crevicular fluid; inflammation; nitric oxide; periodontitis; saliva.

Accepted for publication: 17 June 2014

To cite this article:

Topcu AO, Akalin FA, Sahbazoglu KB, Yamalik N, Kilinc K, Karabulut E, Tözüm TF. Nitrite and Nitrate Levels of Gingival Crevicular Fluid and Saliva in Subjects with Gingivitis and Chronic Periodontitis.

J Oral Maxillofac Res 2014;5(2):e5

URL: http://www.ejomr.org/JOMR/archives/2014/2/e3/v5n2e5ht.pdf

doi: $10.5037 /$ jomr.2014.5205 


\section{INTRODUCTION}

Nitric oxide (NO) is a diatomic free radical synthesized from the conversion of L-arginine to L-citrulline by nitric oxide synthase (NOS) [1]. NO is relatively unstable in the presence of oxygen and quickly auto-oxidized to produce nitrogen oxides. Because of NO's reactivity and short-life, direct measurements of NO in cells and tissues are very difficult [2]. Although NO metabolites have a very short life, nitrate and nitrite are the relatively stable end products of $\mathrm{NO}$ oxidation $[2, \underline{3}]$. The total levels of nitrite and nitrate in biological fluids are generally used for adequate monitoring of the NO synthesis [4]. Traditional diagnostic procedures for periodontal diseases are limited for evaluation of current disease status []․ In order to improve clinical management of periodontal patients, there is a need for the development of new diagnostic tests that can detect the presence of active disease, future disease progression, and evaluate the response to periodontal therapy. Advances in oral and periodontal diagnostic research are moving toward methods by which periodontal risk can be identified and quantified by objective measures such as biomarkers []. Biomarkers of disease play an important role in diagnosis, assessing the treatment outcomes, and drug discovery [7]. In order to understand their role in routine practice, their relation to the mechanism of disease progression and therapeutic intervention must be understood [8].

Gingival crevicular fluid (GCF) is an exudate originating from serum and can be collected from the gingival sulcus surrounding natural teeth $[\underline{9}, \underline{10}]$. The flow of this biological fluid is an important determinant for the status of periodontal tissues, which reflects the cellular response in the periodontium by the constituents of serum and contributions from the gingival crevice [10-12].

Inducible NO synthase (iNOS) is produced by immune system cells such as macrophages infected with bacteria and is involved in the regulation of inflammatory reactions [13]. NO has beneficial and harmful effects and it is involved in the regulation of many physiological issues including platelet aggregation, immune regulation and vascular relaxation $[14,15]$. The activation of iNOS, inflammatory mediators in cells and nitrosative stress are reported to be increased in inflammatory periodontal tissues $[\underline{16}, 17]$. It has been shown that NO takes part in the etiopathogenesis of many diseases, including periodontal disease [18-20]. Overproduction of NO can cause destruction of periodontal tissues [18]. Matejka et al. [21] obtained gingival tissue from patients with moderate periodontitis and from healthy controls in their study and they reported that NO production is increased in inflamed periodontal tissue. In another study, it has been suggested that the expression of iNOS from macrophages in high levels may damage the periodontal tissues. iNOS activity in macrophages was reported to have the potential to inhibit leukocyte recruitment by acting on leukocytes that increase the inflammation in localized aggressive periodontitis (LAP) patients [22].

However, conflicting results of NO metabolites, either decreased or increased in saliva from patients with periodontitis have also been reported [23-26]. In a recent study by Andrukhov et al. [27] significantly lower serum and saliva levels of NO metabolites were found in periodontitis patients.

Evaluation of nitrite and nitrate concentrations which are produced by the biochemical events in immunological response during host-pathogen interaction will play an important role in understanding the etiopathogenesis of periodontal disease. In recent years, exponential data on the involvement of $\mathrm{NO}$ and nitrosative stress in chronic periodontitis has emphasised the need to improve diagnostic parameters [28]. The localization and effects of nitrosative stress may be assessed by an analysis of nitrosative damage biomarkers isolated from tissues and biological fluids [28].

The aim of this study was to measure nitrite and nitrate levels in total saliva and gingival crevicular fluid in patients with gingivitis and chronic periodontitis and to assess the value of these nitrosative stress parameters of periodontal disease.

\section{MATERIAL AND METHODS Ethical aspects}

The study protocol was approved by the Institutional Review Board of the Hacettepe University in accordance with the Helsinki Declaration of 1975, as revised in 2000. All voluntary participants were informed about the outline, purpose of the study and signed an informed consent form. When necessary, periodontal treatment was performed by periodontists (AOT and KBS) after sampling.

\section{Study protocol}

The present study was conducted in the Department of Periodontology between February 2011 and January 2012. A total of 60 individuals, which included, 
20 chronic periodontitis and 20 gingivitis patients and 20 periodontally healthy controls participated in the present study. Ages, gender, number of teeth and smoking habit variables were recorded.

\section{Clinical parameters}

Clinical periodontal status was determined by assessing the probing depth (PD), clinical attachment level (CAL), gingival index (GI), [29], gingival bleeding time index (GBTI) [30] and plaque index (PI) [31] scores. Full-mouth recordings was performed by one examiner (AOT) during the first visit and assigned one of the following study groups.

\section{Inclusion criteria \\ Gingivitis group}

The existence of gingival inflammation (GI values $>0$ ), with $\mathrm{PD}$ values $<3 \mathrm{~mm}$ and $\mathrm{CAL} \leq 2 \mathrm{~mm}$ at more than or equal to $90 \%$ of teeth and no radiographic signs of alveolar bone loss due to periodontal disease (i.e., distance between the cemento-enamel junction and bone crest at $>90 \%$ of the proximal tooth sites $\leq 3 \mathrm{~mm}$ ).

\section{Chronic periodontitis group}

Subjects with presence of sites presenting CAL values $\geq 3 \mathrm{~mm}$ and GI values $>0$ and $\mathrm{PD}$ of $\geq 6 \mathrm{~mm}$ in multiple sites in all four quadrants of the mouth and moderate-to-severe alveolar bone loss (more than $3 \mathrm{~mm}$ ) present in radiographs.

\section{Control group}

Clinically healthy periodontal status, that is, GI values of 0 , PD $\leq 3 \mathrm{~mm}$, no gingival recession and CAL $\leq 2 \mathrm{~mm}$ at more than or equal to $90 \%$ of the measured tooth sites as well as bleeding on probing in less than $10 \%$ of the probing sites at examination and no radiographic evidence of alveolar bone loss in these subjects (i.e., distance between the cemento-enamel junction and bone crest $\leq 3 \mathrm{~mm}$ at $>90 \%$ of the proximal tooth sites).

In addition to the general periodontal status of the subjects, individual periodontal status of the sampled teeth was also considered.

\section{Exclusion criteria}

Exclusion criteria included the following: pregnant or lactating women; subjects used any antibiotics or received periodontal treatment within the last
6 months; subjects on anti-inflammatory therapy, or vitamin/nutritional supplements; and subjects with systemic diseases such as diabetes mellitus, hypertension, renal disease, rheumatoid arthritis, periapical infection of any tooth, or any other form of systemic inflammatory involvement.

\section{Saliva and GCF sampling}

Maxillary teeth including first molars, second premolars, canines and central incisors (eight teeth of each subject) were selected to avoid possible saliva contamination during sampling. Sampled teeth were free of caries, prosthetic reconstruction and root canal therapy. All the samples were collected by one blind examiner (KBS), 48 hours following the clinical measurements in the morning (between 10 a.m. - 11 a.m.) following an overnight fast. Saliva samples were obtained prior to GCF samples. The participants were told not to eat or drink anything or chew gum that morning before sampling. They were asked whether they followed these instructions or not, before collection of the samples. Unstimulated whole saliva samples were obtained over $5 \mathrm{~min}$. periods while they seated. Subjects were asked not to swallow any saliva for the duration of the collection to allow saliva to pool in the bottom of the mouth and collection tube was used to drain when necessary. Saliva samples were then placed in sterile Eppendorf tubes and stored at $-80{ }^{\circ} \mathrm{C}$ until the laboratory analysis. GCF samples were obtained after saliva sampling, according to the method described by Rüdin and colleagues [32], using standardized commercial paper strips (Oraflow Inc., Amityville, NY, USA). Following the isolation of the sampling area with sterile cotton rolls, supragingival plaque was removed and experimental site was gently air dried to reduce any possible contamination with saliva. Extreme care was taken to minimize mechanical irritation during sampling. Paper strips were placed at a standardized depth of $1 \mathrm{~mm}$ at each sampling site independent from PD measurements and were left there for 30 seconds for each sampling. Samples with evidence of bleeding were excluded and sampling was replicated from another site of the natural tooth that was not sampled. To eliminate the risk of evaporation [33], paper strips with GCF were immediately transported to previously calibrated, Periotron 8000 (Oraflow Inc., Amityville, NY, USA) for volume quantification. Before sampling, the Periotron 8000 was switched on and allowed to warm up before a blank paper strip was placed in the device and the reading dial was set to zero [34]. The calibration of the device was checked with periodic intervals and performed 
by triplicate readings as previously described [35]. The GCF was measured electronically in Periotron units, which were converted to micro liters $(\mu 1)$ by MCCONVRT software (Software version 2.52, Oraflow Inc., Amityville, NY, USA). GCF samples were then placed in sterile Eppendorf tubes and stored at $-80{ }^{\circ} \mathrm{C}$ until the day of laboratory analysis.

\section{Determination of nitrite/nitrate level of saliva and GCF}

The stable end products of NO, nitrite, and nitrate were analyzed by Griess reagent as described by Grisham et al. [36], which is based on determination of the nitrate reductase activity in samples. Saliva samples were centrifuged for 5 minutes at 10000 $\mathrm{x} g$ at $4{ }^{\circ} \mathrm{C}$ to remove any particulate matter. The supernatant was used to determine total nitrite levels. To each GCF sample in the Eppendorf Tube, 130 $\mathrm{mL}$ of distilled water was added. The samples were vigorously mixed for the extraction of nitrite into the water. For the determination of nitrite levels, 100 $\mathrm{mL}$ of the extract was mixed with $0,5 \mathrm{ml}$ of freshly prepared Griess reagent, using a micro plate. After 10 minutes of incubation at room temperature, the absorption of each sample in microplate wells was determined at $540 \mathrm{~nm}$ [36]. A standard curve was prepared using sodium nitrite to calculate nitrite and nitrate concentration in saliva and GCF.

\section{Statistical analysis}

Categorical variables were evaluated by Chi-square and extension of Fisher's exact test to $3 \times 3$ table. Parametric data were expressed as mean and standard deviation (M [SD]). Non-parametric KruskalWallis test was used to compare the differences among healthy, gingivitis and periodontitis groups for continuous variables. Pair wise comparisons were done by Dunn test. Correlation between continuous variables was evaluated by Pearson correlation coefficient. For all parameters $\mathrm{P}$ values $<0.05$ were considered to be statistically significant.

\section{RESULTS}

Age, gender, number of teeth present in mouth and smoking habit variables are listed on Table 1. Gender, number of teeth present in mouth and smoking habits did not differ significantly between the groups. On the other hand, mean age of the chronic periodontitis group was significantly higher than periodontally healthy controls (42.65 [8.04] years and 29.9 [2.17] years $)(P<0.05)$. No significant correlation was detected among for all parameters between the groups.

\section{Clinical periodontal parameters}

Data regarding full-mouth $\mathrm{PD}$ and CAL measurements and GI, GBTI, PI scores for the study groups are given at Table 2. The differences in PD, CAL and GI between all groups were significant $(\mathrm{P}<0.001)$. GBTI and PI scores were significantly higher in periodontitis (2.69 [0.53] and 1.19 [0.4]) and gingivitis (2.33 [0.7] and 0.92 [0.39]) groups than the control group $(0.14$ [0.13] and $0.1[0.05])(\mathrm{P}<0.001)$. Difference for these parameters did not reach to a significant level between periodontitis and gingivitis groups $(\mathrm{P}>0.05)$. Table 3 provides information on the descriptive data for clinical parameters, GCF volume and nitrite/ nitrate levels regarding individual evaluation of the sampled teeth. The differences regarding all clinical measurements and GCF volume differed significantly between all groups $(\mathrm{P}<0.001)$. Clinical parameters, including the GCF volumes, demonstrated gradual increases with the presence of gingival inflammation.

Table 1. Data regarding age, gender, number of teeth present and smoking habits

\begin{tabular}{c|c|c|c|c|c|c|c}
\hline & Healthy & Gingivitis & Periodontitis & Test statistics & P & \multicolumn{2}{c}{ Pairwise comparisons } \\
\cline { 5 - 7 } & & & vs & P \\
\hline $\begin{array}{c}\text { Gender } \\
\text { (male - female) }\end{array}$ & $10-10$ & $8-12$ & $9-11$ & $\chi^{2}=0.4$ & 0.817 & - & - \\
\hline $\begin{array}{c}\text { Smokers } \\
\text { (n) }\end{array}$ & 4 & 3 & 8 & $\chi^{2}=6.43$ & 0.106 & - & - \\
\hline $\begin{array}{c}\text { Age } \\
\text { Mean (SD) } \\
\text { (years) }\end{array}$ & $29.9(2.17)$ & $33.9(8.38)$ & $42.65(8.04)$ & $\mathrm{KW}=31.68$ & 0.001 & $1 \mathrm{vs} 3$ & $\mathrm{P}<0.001^{\mathrm{a}}$ \\
\hline $\begin{array}{c}\text { Teeth count } \\
\text { Mean (SD) } \\
\text { (n) }\end{array}$ & $27.9(0.3)$ & $26.95(1.35)$ & $26.35(1.98)$ & $\mathrm{KW}=12.24$ & 0.002 & $1 \mathrm{vs} 3$ & $\mathrm{P}<0.05^{\mathrm{a}}$ \\
\hline
\end{tabular}

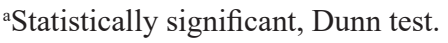

$\mathrm{SD}=$ standard deviation. 
Table 2. Data regarding full-mouth probing depth (PD), clinical attachment level (CAL) measurements (mm), gingival index (GI), gingival bleeding time index (GBTI), plaque index (PI) scores, and saliva nitrite and nitrate level $(\mu \mathrm{M})$ for healthy (1), gingivitis (2) and periodontitis (3) group

\begin{tabular}{|c|c|c|c|c|c|c|c|c|c|c|c|c|c|}
\hline \multirow[b]{2}{*}{ Full-mouth } & \multicolumn{3}{|c|}{ Healthy $(n=147)$} & \multicolumn{3}{|c|}{ Gingivitis $(n=183)$} & \multicolumn{3}{|c|}{ Periodontitis $(n=150)$} & \multicolumn{2}{|c|}{ Difference } & \multicolumn{2}{|c|}{$\begin{array}{c}\text { Pairwise } \\
\text { Comparisons }\end{array}$} \\
\hline & Mean (SD) & Median & Min - Max & Mean (SD) & Median & Min - Max & Mean (SD) & Median & Min - Max & KW & $\mathbf{P}$ & vs & $\mathbf{P}$ \\
\hline \multirow{3}{*}{ PD } & \multirow{3}{*}{$1.35(0.19)$} & \multirow{3}{*}{1.35} & \multirow{3}{*}{$1-1.75$} & \multirow{3}{*}{$1.86(0.25)$} & \multirow{3}{*}{1.9} & \multirow{3}{*}{$1.35-2.38$} & \multirow{3}{*}{$3.26(0.7)$} & \multirow{3}{*}{2.96} & \multirow{3}{*}{$2.13-5$} & \multirow{3}{*}{49.86} & \multirow{3}{*}{$\mathrm{P}<0.001^{\mathrm{a}}$} & 1 vs 2 & $\mathrm{P}<0.05^{\mathrm{a}}$ \\
\hline & & & & & & & & & & & & 1 vs 3 & $\mathrm{P}<0.001^{\mathrm{a}}$ \\
\hline & & & & & & & & & & & & 2 vs 3 & $\mathrm{P}<0.001^{\mathrm{a}}$ \\
\hline \multirow{3}{*}{ CAL } & \multirow{3}{*}{$1.35(0.19)$} & \multirow{3}{*}{1.35} & \multirow{3}{*}{$1-1.75$} & \multirow{3}{*}{$1.89(0.26)$} & \multirow{3}{*}{1.92} & \multirow{3}{*}{$1.35-2.5$} & \multirow{3}{*}{$4.12(0.93)$} & \multirow{3}{*}{4.06} & \multirow{3}{*}{$2.8-5.69$} & \multirow{3}{*}{49.86} & \multirow{3}{*}{$\mathrm{P}<0.001^{\mathrm{a}}$} & 1 vs 2 & $\mathrm{P}<0.05^{\mathrm{a}}$ \\
\hline & & & & & & & & & & & & 1 vs 3 & $\mathrm{P}<0.001^{2}$ \\
\hline & & & & & & & & & & & & 2 vs 3 & $\mathrm{P}<0.001^{\mathrm{a}}$ \\
\hline \multirow{3}{*}{ GI } & & & & & & & & & & & & 1 vs 2 & $\mathrm{P}<0.001^{\circ}$ \\
\hline & $0.16(0.17)$ & 0.09 & $0-0.53$ & $1.2(0.35)$ & 1.24 & $0.45-2.01$ & $1.57(0.3)$ & 1.56 & $1.02-2$ & 43.14 & $\mathrm{P}<0.001^{\mathrm{a}}$ & 1 vs 3 & $\mathrm{P}<0.001^{\circ}$ \\
\hline & & & & & & & & & & & & 2 vs 3 & $\mathrm{P}<0.05^{\mathrm{a}}$ \\
\hline & & & & & & & & & & & & 1 vs 2 & $\mathrm{P}<0.001^{\mathrm{a}}$ \\
\hline GBTI & $0.14(0.13)$ & 0.14 & $0-0.53$ & $2.33(0.7)$ & 2.51 & $0.6-3$ & $2.69(0.53)$ & 3 & $1.21-3$ & 42.51 & $\mathrm{P}<0.001^{\mathrm{a}}$ & 1 vs 3 & $\mathrm{P}<0.001^{\circ}$ \\
\hline & & & & & & & & & & & & 2 vs 3 & $\mathrm{P}>0.05$ \\
\hline & & & & & & & & & & & & 1 vs 2 & $\mathrm{P}<0.001^{2}$ \\
\hline PI & $0.1(0.05)$ & 0.11 & $0.01-0.2$ & $0.92(0.39)$ & 0.87 & $0.28-1.99$ & $1.19(0.4)$ & 1.18 & $0.49-1.98$ & 41.48 & $\mathrm{P}<0.001^{\mathrm{a}}$ & 1 vs 3 & $\mathrm{P}<0.001^{2}$ \\
\hline & & & & & & & & & & & & 2 vs 3 & $\mathrm{P}>0.05$ \\
\hline Saliva & & & & & & & & & & & & 1 vs 2 & \\
\hline nitrite & $8.67(8.68)$ & 5.5 & $0.27-33.14$ & $5.56(4.53)$ & 4.12 & $0.91-16.64$ & $5.55(5.39)$ & 4.12 & $0-18.28$ & 1.34 & $\mathrm{P}>0.05$ & 1 vs 3 & N/A \\
\hline level $(\mu \mathrm{M})$ & & & & & & & & & & & & 2 vs 3 & \\
\hline Saliva & & & & & & & & & & & & 1 vs 2 & \\
\hline nitrate & $20.65(12.2)$ & 21.68 & $0-38.07$ & $18.5(16.7)$ & 9.23 & $0-46.49$ & $16.19(15.49)$ & 15.98 & $0-46.49$ & 1.178 & $\mathrm{P}>0.05$ & 1 vs 3 & N/A \\
\hline level $(\mu \mathrm{M})$ & & & & & & & & & & & & 2 vs 3 & \\
\hline
\end{tabular}

a Statistically significant, Dunn test.

$\mathrm{SD}=$ standard deviation; $\mathrm{N} / \mathrm{A}=$ not available; $\mathrm{KW}=$ Kruskal-Wallis test.

Table 3. Data regarding individual probing depth (PD), clinical attachment level (CAL) measurements (mm), gingival index (GI), gingival bleeding time index (GBTI), plaque index (PI) scores, GCF volume ( $\mu$ l) and total nitrate and nitrate level (nmol) of the sampled teeth

\begin{tabular}{|c|c|c|c|c|c|c|c|c|c|c|}
\hline \multirow[b]{2}{*}{ Sampled teeth } & \multicolumn{2}{|c|}{ Healthy $(n=147)$} & \multicolumn{2}{|c|}{ Gingivitis $(n=183)$} & \multicolumn{2}{|c|}{ Periodontitis $(n=150)$} & \multicolumn{2}{|c|}{ Difference } & \multicolumn{2}{|c|}{ Pairwise comparisons } \\
\hline & Mean (SD) & Min - Max & Mean (SD) & Min - Max & Mean (SD) & Min - Max & KW & $\mathbf{P}$ & vs & $\mathbf{P}$ \\
\hline \multirow{3}{*}{ PD } & \multirow{3}{*}{$1.26(0.37)$} & \multirow{3}{*}{$1-2.33$} & \multirow{3}{*}{$1.84(0.41)$} & \multirow{3}{*}{$1-2.83$} & \multirow{3}{*}{$3.68(0.97)$} & \multirow{3}{*}{$1.66-6.5$} & \multirow{3}{*}{49.59} & \multirow{3}{*}{$\mathrm{P}<0.001^{\mathrm{a}}$} & $1 \mathrm{vs} 2$ & $\mathrm{P}<0.01^{\mathrm{a}}$ \\
\hline & & & & & & & & & 1 vs 3 & $\mathrm{P}<0.001^{\mathrm{a}}$ \\
\hline & & & & & & & & & 2 vs 3 & $\mathrm{P}<0.001^{\mathrm{a}}$ \\
\hline \multirow{3}{*}{ CAL } & \multirow{3}{*}{$1.26(0.37)$} & \multirow{3}{*}{$1-2.33$} & \multirow{3}{*}{$1.89(0.48)$} & \multirow{3}{*}{$1-3$} & \multirow{3}{*}{$4.47(1.33)$} & \multirow{3}{*}{$1.66-8.5$} & \multirow{3}{*}{49.87} & \multirow{3}{*}{$\mathrm{P}<0.001^{\mathrm{a}}$} & 1 vs 2 & $\mathrm{P}<0.01^{\mathrm{a}}$ \\
\hline & & & & & & & & & 1 vs 3 & $\mathrm{P}<0.001^{\mathrm{a}}$ \\
\hline & & & & & & & & & 2 vs 3 & $\mathrm{P}<0.001^{\mathrm{a}}$ \\
\hline \multirow{3}{*}{ GI } & \multirow{3}{*}{$0.01(0.06)$} & \multirow{3}{*}{$0-0.25$} & \multirow{3}{*}{$1.07(0.49)$} & \multirow{3}{*}{$0.25-2.5$} & \multirow{3}{*}{$1.59(0.36)$} & \multirow{3}{*}{$0.75-2.25$} & & & 1 vs 2 & $\mathrm{P}<0.001^{\mathrm{a}}$ \\
\hline & & & & & & & 44.97 & $\mathrm{P}<0.001^{\mathrm{a}}$ & 1 vs 3 & $\mathrm{P}<0.001^{\mathrm{a}}$ \\
\hline & & & & & & & & & 2 vs 3 & $\mathrm{P}>0.05$ \\
\hline & & & & & & & & & 1 vs 2 & $\mathrm{P}<0.001^{\mathrm{a}}$ \\
\hline GBTI & $0.01(0.11)$ & $0-1$ & $2.10(1.07)$ & $1-3$ & $2.78(0.57)$ & $1-3$ & 44.97 & $\mathrm{P}<0.001^{\mathrm{a}}$ & 1 vs 3 & $\mathrm{P}<0.001^{\mathrm{a}}$ \\
\hline & & & & & & & & & 2 vs 3 & $\mathrm{P}>0.05$ \\
\hline & & & & & & & & & $1 \mathrm{vs} 2$ & $\mathrm{P}<0.001^{\mathrm{a}}$ \\
\hline PI & $0.03(0.08)$ & $0-0.25$ & $0.81(0.54)$ & $0-2.5$ & $1.14(0.49)$ & $0.25-2.25$ & 40.80 & $\mathrm{P}<0.001^{\mathrm{a}}$ & 1 vs 3 & $\mathrm{P}<0.001^{\mathrm{a}}$ \\
\hline & & & & & & & & & 2 vs 3 & $\mathrm{P}>0.05$ \\
\hline & & & & & & & & & $1 \mathrm{vs} 2$ & $\mathrm{P}<0.001^{\mathrm{a}}$ \\
\hline GCF volume & $0.32(0.17)$ & $0.05-0.98$ & $0.64(0.43)$ & $0.13-2.57$ & $1.23(0.6)$ & $0.25-2.89$ & 45.56 & $\mathrm{P}<0.001^{\mathrm{a}}$ & 1 vs 3 & $\mathrm{P}<0.001^{\mathrm{a}}$ \\
\hline & & & & & & & & & 2 vs 3 & $\mathrm{P}<0.05^{\mathrm{a}}$ \\
\hline & & & & & & & & & 1 vs 2 & $\mathrm{P}<0.05^{\mathrm{a}}$ \\
\hline (nmol) & $0.83(0.31)$ & $0.26-1.68$ & $1.07(0.62)$ & $0.14-4.93$ & $1.08(0.59)$ & $0-3.72$ & 7.39 & $\mathrm{P}<0.05^{\mathrm{a}}$ & 1 vs 3 & $\mathrm{P}>0.05$ \\
\hline & & & & & & & & & 2 vs 3 & $\mathrm{P}>0.05$ \\
\hline & & & & & & & & & 1 vs 2 & \\
\hline (nmol) & $7.7(2.71)$ & $0-22.88$ & $7.51(4.16)$ & $0-50.4$ & $7.38(1.91)$ & $0.02-15.7$ & 0.43 & $\mathrm{P}>0.05$ & 1 vs 3 & N/A \\
\hline & & & & & & & & & 2 vs 3 & \\
\hline
\end{tabular}

a'Statistically significant, Dunn test.

$\mathrm{SD}=$ standard deviation; $\mathrm{N} / \mathrm{A}=$ not available. 


\section{Nitrite/nitrate levels in saliva and GCF}

Salivary nitrite/nitrate levels $(\mu \mathrm{M})$ for the study groups are given at Table 2. Salivary nitrite/ nitrate levels did not differ significantly among the three study groups. Total nitrite levels in GCF were higher in periodontitis and gingivitis (1.08 [0.59] nmol and 1.07 [0.62]) groups than the control group $(0.83 \quad[0.31] \mathrm{nmol})$ $(\mathrm{P}<0.001)$. The difference in GCF nitrite level did not reach to a significant level between gingivitis and periodontitis groups $(\mathrm{P}>0.05)$. GCF nitrate level did not differ significantly among the control, gingivitis and periodontitis groups $(7.7$ [2.71] nmol, 7.51 [4.16] nmol and $7.38[1.91] \mathrm{nmol})(\mathrm{P}>0.05)$.

\section{Analysis of nitrate/nitrite ratio in saliva and GCF}

In the present study, nitrate/nitrite ratios in saliva and GCF were also evaluated; the ratio was calculated with the division of nitrate by nitrite. Saliva nitrate/ nitrite ratios were higher in periodontitis and gingivitis groups (2.91 and 3.32) than the control group. On the other hand, GCF nitrate/nitrite ratio demonstrated a gradual decrease with the presence of inflammation.

\section{DISCUSSION}

NO is an important inflammatory mediator which shows both direct and indirect effects. Direct effects include the chemical reactions on its biological target. The indirect effects involve the actions of NO metabolites; reactive nitrogen species (RNS). The indirect effects can then subdivide to nitrosative stress and oxidative stress $[28, \underline{37}]$. An excess of reactive oxygen species (ROS) and depletion of anti-oxidant levels in tissues results with oxidative stress [38,39]. The indirect effects need NO, activated by superoxide $\left(\mathrm{O}_{2}\right)$ or oxygen to form RNS, then undergo consecutive reactions with their related biological targets $[\underline{28}, \underline{37}]$. Nitrosative stress also involves intermediates, produced from nitrosated thiol, hydroxy, and amine groups [37]. Oxidative and nitrosative stress are involved in many diseases and medical conditions, such as cancer, diabetes, atherosclerosis, congestive heart failure, myocardial infarction, metabolic syndrome and periodontitis [39-41]. A recent study has demonstrated the involvement of nitrosative stress in the aggravation of periodontitis under a diabetic condition, suggesting that nitrosative stress plays a crucial role in the development of diabetic- associated periodontitis [17]. In another recent study, Subantimicrobial Dose Doxycycline (SDD) therapy was used as an adjunct to SRP treatment against nitrosative stress in chronic periodontitis. Adjunctive SDD therapy was useful against inflammatory response by reducing the generation of nitrosative stress via inhibiting iNOS. Nitrosative stress reduction was correlated with improvements in periodontal status. The results suggested the utility of nitrosative markers in chronic periodontitis diagnosis and prognosis [28].

NO has been shown to have a paradoxical relationship with bone $[42,43]$. Although excessive production of NO may be associated with bone loss in some inflammatory conditions, $\mathrm{NO}$ also mediates beneficial effects of estrogen on bone by the $\mathrm{NO} /$ cyclic guanosine monophosphate pathway [44]. Knockout mice deficient in endothelial NOS exhibit osteoporosis as a result of a defect in bone formation [15]. Similarly, mice that are deficient in iNOS exhibit altered bone healing [45]. Increased bone mineral density has been reported in mice deficient in all three isoforms of NOS [46]. On the other hand, in response to inflammation, iNOS is expressed, resulting in higher amounts of NO production $[14,15]$. Increased numbers of iNOS positive cells have been demonstrated in periodontally diseased tissues [47-49]. Another previous study has demonstrated that enhanced formation of NO, increased iNOS production and consequent nitrosative stress play a significant role in the pathogenesis of periodontitis [16].

In the present study, we evaluated nitrite and nitrate levels in GCF and saliva from patients with generalized gingivitis and chronic periodontitis. The level of nitrite in GCF of 147 healthy, 183 gingivitis and 150 chronic periodontitis sites were analyzed. In accordance with the literature [5052], the findings of this study demonstrated that GCF volumes exhibited clear increases at diseased sites compared to healthy sites. Also the present study shows that inflammatory conditions increases GCF nitrite level significantly in comparison with control subjects. Comparable findings have been reported previously [53]. They studied nitrite and myeloperoxidase metabolism in both GCF and peri-implant sulcular fluid, and demonstrated a tendency to increase in these ingredients with the presence of gingival/peri-implant inflammation. On the other hand, in the present study, nitrate levels did not differ significantly among study groups. In order to evaluate the change in levels of nitrite and nitrate according to each other, nitrate/nitrite ratio was calculated. The gradual decrease in nitrate/ 
nitrite ratio with the presence of inflammation and higher nitrite level in inflamed groups emphasizes that role of the nitrite in periodontal disease pathogenesis is more pronounced than nitrate. It might be speculated that nitrite may be a more beneficial indicator than nitrate.

NO production in saliva was also measured using the level of nitrite/nitrate in saliva of 20 gingivitis and 20 chronic periodontitis and 20 control subjects. Analyses demonstrated no significant difference among the study groups regarding saliva nitrite level. Almost equal nitrate levels in inflammatory groups may be due to quite similar values for the presence/extent of gingival inflammation and plaque accumulation detected in full mouth recording of gingivitis and chronic periodontitis groups or large overlap between study groups.

Based on the previously demonstrated discrepancy between "concentration" and "total activity" modes of data presentation for GCF, were not completely correlated $[\underline{54}, \underline{55}]$. With respect to total activity level, nitrite and nitrate concentrations in gingivitis or periodontitis were lower than healthy sites. This contrast between 2 modes of data presentation suggests the volume-dependent nature of the concentration expression. As the available GCF volume in a given site affects concentration expression, it may be suggested that GCF share similar volumetric features with respect to the appropriate mode of data presentation.

In the present study, two biological fluids, GCF and saliva, were analyzed. Although the results may shed light on the diagnostic potential of GCF, the results regarding saliva NO level still remain controversial.

Nitrite and nitrate levels did not demonstrate any significant correlation between these two biological fluids. Saliva can be affected qualitatively and quantitatively by a variety of factors. The broad similarity of clinical parameters, in particular with regard to $\mathrm{PD}$, could explain the non-significant results between gingivitis and periodontitis sites concerning nitrite/nitrate levels. On the other hand, qualitative and quantitative evaluation of GCF is more specific for periodontal disease pathogenesis than saliva. It can be suggested that certain amount of NO is derived from GCF to the saliva. Further studies on this to evaluate and compare the components of saliva and GCF, especially with respect to the inflammatory process, NO and nitrosative stress, are needed to increase our understanding of the role of each component and the diagnostic potential of these parameters and pathogenesis of periodontal disease.

\section{CONCLUSIONS}

In the limits of the present study it can be suggested that gingival crevicular fluid seems to have a better diagnostic potential than saliva. Nitrite may be a better marker for gingival inflammation rather than periodontitis.

\section{ACKNOWLEDGMENTS AND DISCLOSURE STATEMENTS}

This study is supported by Hacettepe University, Scientific Research Projects Coordination Unit, Ankara, Turkey. The authors report no conflicts of interest related to this study.

\section{REFERENCES}

1. Jenkins DC, Charles IG, Thomsen LL, Moss DW, Holmes LS, Baylis SA, Rhodes P, Westmore K, Emson PC, Moncada S. Roles of nitric oxide in tumor growth. Proc Natl Acad Sci U S A. 1995 May 9;92(10):4392-6. [Medline: 7538668] [PMC free article: 41950] [doi: 10.1073/pnas.92.10.4392]

2. Uğar-Cankal D, Ozmeric N. A multifaceted molecule, nitric oxide in oral and periodontal diseases. Clin Chim Acta. 2006 Apr;366(1-2):90-100. Epub 2006 Jan 4. Review. [Medline: 16387291]

3. Lappin DF, Kjeldsen M, Sander L, Kinane DF. Inducible nitric oxide synthase expression in periodontitis. J Periodontal Res. 2000 Dec;35(6):369-73. [Medline: 11144410] [doi: 10.1034/j.1600-0765.2000.035006369.x]

4. Moshage H, Kok B, Huizenga JR, Jansen PL. Nitrite and nitrate determinations in plasma: a critical evaluation. Clin Chem. 1995 Jun;41(6 Pt 1):892-6. [Medline: 7768008]

5. Taba M Jr, Kinney J, Kim AS, Giannobile WV. Diagnostic biomarkers for oral and periodontal diseases. Dent Clin North Am. 2005 Jul;49(3):551-71, vi. Review. [Medline: 15978241] [PMC free article: 2580776] [doi: 10.1016/j.cden.2005.03.009]

6. de Souza SL, Taba M Jr. Cross-sectional evaluation of clinical parameters to select high prevalence populations for periodontal disease: the site comparative severity methodology. Braz Dent J. 2004;15(1):46-53. Epub 2004 Aug 16. [Medline: 15322645] [doi: 10.1590/S0103-64402004000100009] 
7. Teles R, Sakellari D, Teles F, Konstantinidis A, Kent R, Socransky S, Haffajee A. Relationships among gingival crevicular fluid biomarkers, clinical parameters of periodontal disease, and the subgingival microbiota. J Periodontol. 2010 Jan;81(1):89-98 [Medline: 20059421] [PMC free article: 2805280] [doi: 10.1902/jop.2009.090397]

8. Colburn WA. Biomarkers in drug discovery and development: from target identification through drug marketing. J Clin Pharmacol. 2003 Apr;43(4):329-41. Review. [Medline: 12723454] [doi: $10.1177 / 0091270003252480$ ]

9. Perozini C, Chibebe PC, Leao MV, Queiroz Cda S, Pallos D. Gingival crevicular fluid biochemical markers in periodontal disease: a cross-sectional study. Quintessence Int. 2010 Nov-Dec;41(10):877-83. [Medline: 20927426]

10. Guentsch A, Kramesberger M, Sroka A, Pfister W, Potempa J, Eick S. Comparison of gingival crevicular fluid sampling methods in patients with severe chronic periodontitis. J Periodontol. 2011 Jul;82(7):1051-60. Epub 2011 Jan 14. [Medline: 21235330] [PMC free article: 3129431] [doi: 10.1902/jop.2011.100565]

11. Armitage GC. Clinical evaluation of periodontal diseases. Periodontol 2000. 1995 Feb;7:39-53. Review. [Medline: 9567929] [doi: 10.1111/j.1600-0757.1995.tb00035.x]

12. Greenstein G. Contemporary interpretation of probing depth assessments: diagnostic and therapeutic implications. A literature review. J Periodontol. 1997 Dec;68(12):1194-205. Review. [Medline: 9444595] [doi: 10.1902/jop.1997.68.12.1194]

13. Nussler AK, Billiar TR. Inflammation, immunoregulation, and inducible nitric oxide synthase. J Leukoc Biol. 1993 Aug;54(2):171-8. [Medline: 7689630]

14. Brennan PA, Thomas GJ, Langdon JD. The role of nitric oxide in oral diseases. Arch Oral Biol. 2003 Feb;48(2):93100. Review. [Medline: 12642227 ] [doi: 10.1016/S0003-9969(02)00183-8]

15. van't Hof RJ, Ralston SH. Nitric oxide and bone. Immunology. 2001 Jul;103(3):255-61. Review. [Medline: 11454054] [PMC free article: 1783253] [doi: 10.1046/j.1365-2567.2001.01261.x]

16. Lohinai Z, Benedek P, Fehér E, Györfi A, Rosivall L, Fazekas A, Salzman AL, Szabó C. Protective effects of mercaptoethylguanidine, a selective inhibitor of inducible nitric oxide synthase, in ligature-induced periodontitis in the rat. Br J Pharmacol. 1998 Feb;123(3):353-60. Erratum in: Br J Pharmacol 1998 Apr;123(8):741. [Medline: 9504374] [PMC free article: 1565171] [doi: 10.1038/sj.bjp.0701604]

17. Nishikawa T, Naruse K, Kobayashi Y, Miyajima S, Mizutani M, Kikuchi T, Soboku K, Nakamura N, Sokabe A, Tosaki T, Hata M, Ohno N, Noguchi T, Matsubara T. Involvement of nitrosative stress in experimental periodontitis in diabetic rats. J Clin Periodontol. 2012 Apr;39(4):342-9. Epub 2012 Jan 26. [Medline: 22276937] [doi: 10.1111/j.1600-051X.2011.01848.x]

18. Batista AC, Silva TA, Chun JH, Lara VS. Nitric oxide synthesis and severity of human periodontal disease. Oral Dis. 2002 Sep;8(5):254-60. [Medline: 12363110] [doi: 10.1034/j.1601-0825.2002.02852.x]

19. Stea S, Visentin M, Donati ME, Granchi D, Ciapetti G, Sudanese A, Toni A. Nitric oxide synthase in tissues around failed hip prostheses. Biomaterials. 2002 Dec;23(24):4833-8. [Medline: 12361623] [doi: 10.1016/S0142-9612(02)00236-3]

20. Ohashi M, Iwase M, Nagumo M. Elevated production of salivary nitric oxide in oral mucosal diseases. J Oral Pathol Med. 1999 Sep;28(8):355-9. [Medline: 10478960] [doi: 10.1111/j.1600-0714.1999.tb02053.x]

21. Matejka M, Partyka L, Ulm C, Solar P, Sinzinger H. Nitric oxide synthesis is increased in periodontal disease. J Periodontal Res. 1998 Nov;33(8):517-8. [Medline: 9879526] [doi: 10.1111/j.1600-0765.1998.tb02352.x]

22. Gaspirc B, Masera A, Skaleric U. Immunolocalization of inducible nitric oxide synthase in localized juvenile periodontitis patients. Connect Tissue Res. 2002;43(2-3):413-8. [Medline: 12489192] [doi: 10.1080/03008200290000628]

23. Aurer A, Aleksić J, Ivić-Kardum M, Aurer J, Culo F. Nitric oxide synthesis is decreased in periodontitis. J Clin Periodontol. 2001 Jun;28(6):565-8. [Medline: 11350524] [doi: 10.1034/j.1600-051x.2001.028006565.x]

24. Reher VG, Zenóbio EG, Costa FO, Reher P, Soares RV. Nitric oxide levels in saliva increase with severity of chronic periodontitis. J Oral Sci. 2007 Dec;49(4):271-6. [Medline: 18195509] [doi: 10.2334/josnusd.49.271]

25. Ozer L, Elgun S, Ozdemir B, Pervane B, Ozmeric N. Arginine-nitric oxide-polyamine metabolism in periodontal disease. J Periodontol. 2011 Feb;82(2):320-8. Epub 2010 Sep 10. [Medline: 20831369] [doi: 10.1902/jop.2010.100199]

26. Parwani SR, Chitnis PJ, Parwani RN. Salivary nitric oxide levels in inflammatory periodontal disease - a casecontrol and interventional study. Int J Dent Hyg. 2012 Feb;10(1):67-73. Epub 2011 May 12. [Medline: 21564536] [doi: 10.1111/j.1601-5037.2011.00508.x]

27. Andrukhov O, Haririan H, Bertl K, Rausch WD, Bantleon HP, Moritz A, Rausch-Fan X. Nitric oxide production, systemic inflammation and lipid metabolism in periodontitis patients: possible gender aspect. J Clin Periodontol. 2013 Oct;40(10):916-23. Epub 2013 Aug 19. [Medline: 23952303] [doi: 10.1111/jepe.12145]

28. Pârvu AE, Alb SF, Crăciun A, Taulescu MA. Efficacy of subantimicrobial-dose doxycycline against nitrosative stress in chronic periodontitis. Acta Pharmacol Sin. 2013 Feb;34(2):247-54. Epub 2012 Nov 12. [Medline: 23147558] [doi: 10.1038/aps.2012.129] 
29. Loe H, Silness J. Periodontal Disease in Pregnancy. I. Prevalence and Severity. Acta Odontol Scand. 1963 Dec;21:533-51. [Medline: 14121956] [doi: 10.3109/00016356309011240]

30. Nowicki D, Vogel RI, Melcer S, Deasy MJ. The gingival bleeding time index. J Periodontol. 1981 May;52(5):260-2. [Medline: 7017104] [doi: 10.1902/jop.1981.52.5.260]

31. Silness J, Loe H. Periodontal Disease in Pregnancy. II. Correlation between Oral Hygiene and Periodontal Condtion. Acta Odontol Scand. 1964 Feb;22:121-35. [Medline: 14158464] [doi: 10.3109/00016356408993968]

32. Rüdin HJ, Overdiek HF, Rateitschak KH. Correlation between sulcus fluid rate and clinical and histological inflammation of the marginal gingiva. Helv Odontol Acta. 1970 Apr;14(1):21-6. [Medline: 5438796]

33. Tözüm TF, Hatipoğlu H, Yamalik N, Gürsel M, Alptekin NO, Ataoğlu T, Marakoğlu I, Gürsoy UK, Eratalay K. Critical steps in electronic volume quantification of gingival crevicular fluid: the potential impact of evaporation, fluid retention, local conditions and repeated measurements. J Periodontal Res. 2004 Oct;39(5):344-57. [Medline: 15324356] [doi: 10.1111/j.1600-0765.2004.00758.x]

34. Chapple IL, Landini G, Griffiths GS, Patel NC, Ward RS. Calibration of the Periotron 8000 and 6000 by polynomial regression. J Periodontal Res. 1999 Feb;34(2):79-86. [Medline: 10207836] [doi: 10.1111/j.1600-0765.1999.tb02226.x]

35. Deinzer R, Mossanen BS, Herforth A. Methodological considerations in the assessment of gingival crevicular fluid volume. J Clin Periodontol. 2000 Jul;27(7):481-8. [Medline: 10914888] [doi: 10.1034/j.1600-051x.2000.027007481.x]

36. Grisham MB, Johnson GG, Gautreaux MD, Berg RD. Measurement of nitrate and nitrite in extracellular fluids: a window to systemic nitric oxide metabolism. Methods. 1995 Jan; 7(1):84-90. [doi: 10.1006/meth.1995.1012]

37. Caton J, Ryan ME. Clinical studies on the management of periodontal diseases utilizing subantimicrobial dose doxycycline (SDD). Pharmacol Res. 2011 Feb;63(2):114-20. Epub 2010 Dec 21. Review. [Medline: 21182947] [doi: 10.1016/j.phrs.2010.12.003]

38. Konopka T, Król K, Kopeć W, Gerber H. Total antioxidant status and 8-hydroxy-2'-deoxyguanosine levels in gingival and peripheral blood of periodontitis patients. Arch Immunol Ther Exp (Warsz). 2007 Nov-Dec;55(6):417-22. Epub 2007 Dec 3. [Medline: 18060366] [PMC free article: 2766448] [doi: 10.1007/s00005-007-0047-1]

39. Chapple IL, Matthews JB. The role of reactive oxygen and antioxidant species in periodontal tissue destruction. Periodontol 2000. 2007;43:160-232. [Medline: 17214840] [doi: 10.1111/j.1600-0757.2006.00178.x]

40. Valko M, Leibfritz D, Moncol J, Cronin MT, Mazur M, Telser J. Free radicals and antioxidants in normal physiological functions and human disease. Int J Biochem Cell Biol. 2007;39(1):44-84. Epub 2006 Aug 4. Review. [Medline: 16978905] [doi: 10.1016/j.biocel.2006.07.001]

41. Baltacioğlu E, Akalin FA, Alver A, Değer O, Karabulut E. Protein carbonyl levels in serum and gingival crevicular fluid in patients with chronic periodontitis. Arch Oral Biol. 2008 Aug;53(8):716-22. Epub 2008 Mar 17. [Medline: 18346710] [doi: 10.1016/j.archoralbio.2008.02.002]

42. D’Aiuto F, Nibali L, Parkar M, Patel K, Suvan J, Donos N. Oxidative stress, systemic inflammation, and severe periodontitis. J Dent Res. 2010 Nov;89(11):1241-6. Epub 2010 Aug 25. [Medline: 20739696] [PMC free article: 3318025] [doi: 10.1177/0022034510375830]

43. Thomas MV, Puleo DA. Infection, inflammation, and bone regeneration: a paradoxical relationship. J Dent Res. 2011 Sep;90(9):1052-61. Epub 2011 Jan 19. Review. [Medline: 21248364] [PMC free article: 3169879] [doi: $10.1177 / 0022034510393967]$

44. Wimalawansa SJ. Nitric oxide and bone. Ann N Y Acad Sci. 2010 Mar;1192:391-403. Review. [Medline: 20392265] [doi: 10.1111/j.1749-6632.2009.05230.x]

45. Saura M, Tarin C, Zaragoza C. Recent insights into the implication of nitric oxide in osteoblast differentiation and proliferation during bone development. ScientificWorldJournal. 2010 Apr 13;10:624-32. Review. [Medline: 20419275] [doi: $10.1100 /$ tsw.2010.58]

46. Sabanai K, Tsutsui M, Sakai A, Hirasawa H, Tanaka S, Nakamura E, Tanimoto A, Sasaguri Y, Ito M, Shimokawa H, Nakamura T, Yanagihara N. Genetic disruption of all NO synthase isoforms enhances BMD and bone turnover in mice in vivo: involvement of the renin-angiotensin system. J Bone Miner Res. 2008 May;23(5):633-43. [Medline: 18433298] [doi: 10.1359/jbmr.080107]

47. Hirose M, Ishihara K, Saito A, Nakagawa T, Yamada S, Okuda K. Expression of cytokines and inducible nitric oxide synthase in inflamed gingival tissue. J Periodontol. 2001 May;72(5):590-7. [Medline: 11394393] [doi: 10.1902/jop.2001.72.5.590]

48. Shibata K, Warbington ML, Gordon BJ, Kurihara H, Van Dyke TE. Nitric oxide synthase activity in neutrophils from patients with localized aggressive periodontitis. J Periodontol. 2001 Aug;72(8):1052-8. [Medline: 11525437] [doi: 10.1902/jop.2001.72.8.1052]

49. Daghigh F, Borghaei RC, Thornton RD, Bee JH. Human gingival fibroblasts produce nitric oxide in response to proinflammatory cytokines. J Periodontol. 2002 Apr;73(4):392-400 [Medline: 11990440] [doi: 10.1902/jop.2002.73.4.392]

50. Tözüm TF, Türkyilmaz I, Yamalik N, Tümer C, Kilinç A, Kilinç K, Karabulut E, Eratalay K. Analysis of thte possible impact of inflammation severity and early and delayed loading on nitric oxide metabolism around dental implants. Int J Oral Maxillofac Implants. 2005 Jul-Aug;20(4):547-56. [Medline: 16161739] 
51. Ozkavaf A, Aras H, Huri CB, Mottaghian-Dini F, Tözüm TF, Etikan I, Yamalik N, Caglayan F. Relationship between the quantity of gingival crevicular fluid and clinical periodontal status. J Oral Sci. 2000 Dec;42(4):231-8. [Medline: 11269382] [doi: 10.2334/josnusd.42.231]

52. Hatipoğlu H, Yamalik N, Berberoğlu A, Eratalay K. Impact of the distinct sampling area on volumetric features of gingival crevicular fluid. J Periodontol. 2007 Apr;78(4):705-15. [Medline: 17397319] [doi: 10.1902/jop.2007.060331]

53. Tözüm TF, Akman AC, Yamalik N, Tulunoglu I, Turkyilmaz I, Karabulut E, Kilinc K, Cehreli MC. Analysis of the inflammatory process around endosseous dental implants and natural teeth: myeloperoxidase level and nitric oxide metabolism. Int J Oral Maxillofac Implants. 2007 Nov-Dec;22(6):969-79. [Medline: 18271379]

54. Yamalik N, Cağlayan F, Kilinç K, Kilinç A, Tümer C. The importance of data presentation regarding gingival crevicular fluid myeloperoxidase and elastase-like activity in periodontal disease and health status. J Periodontol. 2000 Mar;71(3):460-7. [Medline: 10776935] [doi: 10.1902/jop.2000.71.3.460]

55. Lamster IB, Oshrain RL, Fiorello LA, Celenti RS, Gordon JM. A comparison of 4 methods of data presentation for lysosomal enzyme activity in gingival crevicular fluid. J Clin Periodontol. 1988 Jul;15(6):347-52. [Medline: 3042812] [doi: 10.1111/j.1600-051X.1988.tb01010.x]

\section{To cite this article:}

Topcu AO, Akalin FA, Sahbazoglu KB, Yamalik N, Kilinc K, Karabulut E, Tözüm TF. Nitrite and Nitrate Levels of Gingival Crevicular Fluid and Saliva in Subjects with Gingivitis and Chronic Periodontitis.

J Oral Maxillofac Res 2014;5(2):e5

URL: http://www.ejomr.org/JOMR/archives/2014/2/e5/v5n2e5ht.pdf

doi: $10.5037 /$ jomr.2014.5205

Copyright (C) Topcu AO, Akalin FA, Sahbazoglu KB, Yamalik N, Kilinc K, Karabulut E, Tözüm TF. Published in the JOURNAL OF ORAL \& MAXILLOFACIAL RESEARCH (http://www.ejomr.org), 1 July 2014.

This is an open-access article, first published in the JOURNAL OF ORAL \& MAXILLOFACIAL RESEARCH, distributed under the terms of the Creative Commons Attribution-Noncommercial-No Derivative Works 3.0 Unported License, which permits unrestricted non-commercial use, distribution, and reproduction in any medium, provided the original work and is properly cited. The copyright, license information and link to the original publication on (http://www.ejomr.org) must be included. 